\title{
Estimation of Foreign Trade Volume Between Turkey and BRICs with Gravity Model
}

\author{
Nevzat BALIKCIOGLU \\ Assistant Professor, Faculty of Economics and Administrative Sciences, Department of Economics Sivas \\ Cumhuriyet University, Sivas, Turkey
}

\begin{abstract}
Özet
Bu çalışma Türkiye ile BRICS (Brezilya, Rusya, Hindistan, Çin ve Güney Afrika Cumhuriyeti) ülkeleri arasındaki diş ticaret hacminin yerçekimi modeli ile tahmin edilmesini ele almaktadır. Panel regresyon analizi ile 1992-2016 yılları arasında ele alınan ülkelerin GSYH'ları, nüfus miktarları ile ülkeler arasındaki mesafenin yer aldığı tahmin modellerinde, ticaret hacmi bağımlı değişken olarak değerlendirilmiş̧tir. Yapılan analizde nüfusun dâhil olduğu tahmin modelinin sonuçları yerçekimi modelinin üzerine oturduğu tezi doğrular niteliktedir. Sonuçlar anlamlı ve katsayılar beklenen işaretleri taşımaktadır.

Anahtar kelimeler: Yerçekimi Modeli (Gravity Model), Panel Regresyon, BRICS, Türkiye

Abstract

This study deals with estimating the volume of foreign trade between Turkey and BRICS countries (Brazil, Russia, India, China and South Africa) with the gravity model. In the estimation models where GDP and population amounts of the countries, which were evaluated in the years between 1992 and 2016, and the distance between countries are included, trade volume is considered as dependent variable. In the analysis, the results of the estimation model, including the population, confirm the hypothesis that gravity is based on the model. The results are meaningful and the coefficients bear the expected marks.
\end{abstract}

Keywords: Gravity Model, Panel Regression, BRICS, Turkey

DOI: $10.7176 / \mathrm{EJBM} / 11-9-02$

Publication date:March $31^{\text {st }} 2019$

\section{Introduction}

Turkey's foreign trade volume gained momentum after the 1980s. Since the ratio of exports to imports is always below one, it has given a continuous foreign trade deficit. However, the volume of foreign trade has increased both in exports and imports. In this study, Turkey's foreign trade volume of his 25 years with the BRICS countries between the years 1992 to 2016 is considered to be confirmed by the gravity model. BRICS countries, which are among the developing economies of the world, include five countries, namely Brazil, Russia, India, China and South Africa. The Gravity Model, the application of Newton's gravitational law to the foreign trade of countries, has a history dating back to the 1960s. This model, which is applied in different versions, is applied to BRICS countries and its results are discussed.

The BRICS countries, which constituted 6\% of Turkey's foreign trade volume in 1992, increased to around $18 \%$ in 2016. In order to monitor the progress of this important development, the course of trade volume is discussed by using gravity model. It is important to remember that all of these countries are within G20 countries. These countries are among the 20 countries with the highest GDP in the world.

The gravity model is the adaptation of gravity power to the international trade volume, capital flow or migration flow in a similar way. The trade flow between model countries is estimated by associating the countries ' GNP with the distance between them and the population. This model has a number of application formats. Only a few examples will be studied here.

The name gravitational force (Gij), which takes its name from Newton's gravitational force law, is defined as the gravity equation

$$
G_{i j}=\frac{M_{i} M_{j}}{D_{i j}}
$$

Here $\mathrm{M}_{\mathrm{i}}$ and $\mathrm{M}_{\mathrm{j}}$ are the mass of different objects, while Dij is the distance between the objects. The logarithms for estimating this equation will be transformed into the following format;

$$
\ln G_{i j}=\ln M_{i}+\ln M_{j}-\ln D_{i j}
$$

To convert the above equation to an economic meaning, $E_{\mathrm{i} i}$, shows the volume of a I country to a $j$ country (export), and the masses show the GDPs of the $i$ and $j$ countries. The distance between the two countries is shown as Dij.

$$
\ln E_{i j}=\alpha+\beta_{1} \ln G D P_{i}+\beta_{2} \ln G D P_{j}+\beta_{3} \ln D_{i j}
$$

When economic applications are considered, it is expected that $\beta 3$ is $<0$ when $\beta 1$ and $\beta 2$ are $>0$. Again, there 
are a number of improved versions of the same equation. Here, a few of the equations including the population can be written as follows.

$$
\ln E_{i j}=\alpha+\beta_{1} \ln G D P_{i}+\beta_{2} \ln P O P_{i}+\beta_{3} \ln G D P_{j}+\beta_{4} \ln P O P_{j}+\beta_{5} \ln D_{\mathrm{ij}}
$$

or, it can be written as.

$$
\ln E_{i j}=\alpha+\beta_{1} \ln \left(G D P_{i} / P O P_{i}\right)+\beta_{2} \ln \left(G D P_{j} / P O P_{j}\right)+\beta_{3} \ln D_{i j}
$$

In these equations, POPi and POPj show the number of populations belonging to $i$ and $j$ countries.

Some problems arise in applications of gravity model. The autocorrelation problem arises between the two countries. The way to avoid this kind of negativity is the use of data sets spread across a number of countries and over the years. The most appropriate estimation method for this is panel regression method.

The model has been successfully applied to flows of varying types such migration, foreign direct investment and, more specifically, to international trade flows. Gravity models can be augmented with additional variables that can foster or damage international trade, such as geographical, social, cultural, linguistic, integration and infrastructure variables.

\section{Literature}

The first formulation of gravity model based on Newton's Law of universal gravitation was made by Tinbergen (1962). Analogy with physics served perfectly as a logical explanation of trade flow between countries. Other authors like Armington (1969), Anderson (1979), Bergstrand (1985), Helpman and Krugman (1985) and Brun et. al. (2005) also gave their contribution to the extension of the model which will be discussed later on.

Anderson (1979) was the first to do this, employing the product differentiation by country of origin assumption, commonly known as the "Armington assumption" (Armington, 1969). By specifying demand in these terms, Anderson helped to explain the presence of income variables in the gravity model, as well as their multiplicative (or log linear) form. This approach was also adopted by Bergstrand (1985) who more thoroughly specified the supply side of economies. The result was the insight that prices in the form of GDP deflators might be an important additional variable to include in the gravity equations described above.

The monopolistic competition model of new trade theory has been another approach to providing theoretical foundations to the gravity model (Helpman, 1987 and Bergstrand, 1989). Here, the product differentiation by country of origin approach is replaced by product differentiation among producing firms, and the empirical success of the gravity model is considered to be supportive of the monopolistic competition explanation of intra-industry trade. However, Deardorff (1998) and Feenstra (2004) have cast doubt on this interpretation, noting the compatibility of the gravity equation with some forms of the Heckscher-Ohlin model and, consequently, the need for empirical evidence to distinguish among potential theoretical bases: product differentiation by country of origin; product differentiation by firm; and particular forms of Heckscher-Ohlin-based comparative advantage. In each of these cases, the common denominator is complete specialization by countries in a particular good. Without this feature, bilateral trade tends to become indeterminate.

Later, Helpman (1981) and Helpman and Krugman (1985) integrated monopolistic competition into a Heckscher-Ohlin framework. More recently, Deardorff (1998) derived gravity equation from two cases of the Heckscher- Ohlin theory. These papers now provide the previously missing theoretical underpinnings for the gravity model. Consequently, Evenett and Keller (1998) showed how the data can be used to discriminate between the two alternative trade theories and thus found theoretical support for both in gravity models. Based on the Helpman and Krugman (1985) model that successfully incorporates monopolistic competition of the increasing returns theory into a Heckscher-Ohlin framework.

According to Ekanayake (2010); The coefficients of per capita GDP, population, and distance had expected signs and magnitudes in all models estimated. This confirms the results of other studies. The rapidly evolving economic and political climates provide many opportunities for the investigation of the success of economic integration in Asia.

The main result that Ata (2013) reached in his conference paper titled "Trade Potential between Turkey and its neighbours: a review in the framework of Gravity model " is that Turkey is under the potential of exports with many neighbouring countries and is available for development. According to the model's Estimation results, Turkey's foreign trade is negatively influenced by the economic magnitude of the country's economy, the size of the population and the distance between them.

According to the study of Julian Frede and Hakan Yetkiner (2017; they can state that results are optimistic for Turkey, as its trade patterns show special relations with all neighbouring regions. This could lead to the country assuming the position of a regional bridge-builder, with balanced relations across the wider region including Europe, Africa, the Middle East, and Western Asia (Russia, Caucasus, and Central Asia). Increasing trade with Turkey shows the increasing momentum of the emerging neighbouring regions. While this increasing importance cannot be denied, this does not necessarily imply a decrease in absolute terms of the importance of trade and 
political relations with either the EU or the 'West' in general; rather it reflects the emergence of a more diversified pattern of economic and political attraction, due to the development and expansion of trade patterns.

\section{Estimation Method}

Although the gravity model can be used in a number of areas, it cannot be used in models where some unchanging variables such as race, gender, etc. are used. In model applications, linearity and autocorrelation effect occur in estimations. When using the model, multiple countries and multiple dates will be more convenient. For this reason, the trade volume is dependent on the dependent variable, the countries' GDP and the distance between the population and the countries are considered as independent variables.

Using the model regression estimation method, multiple models were applied. The most appropriate one was chosen by the statistical tests in the selection of the appropriate panel regression equation. In this study, the total trade volume of Turkey with the country it was taken as the basis. In other words, the foreign trade volume of each country with Turkey (= import + export) is considered dependent variable. Below is brief information about panel econometrics;

There is quite a large literature on panel econometrics. Baltagi, B. H. (2008) (2008), Hsiao (2003), Greene (2003) Gaujarati (2009 2003) among the main sources of panel econometrics. The equation formulas related to panel econometrics are as follows.

\subsection{Estimation of Panel and Pooled Models}

Panel data sets are data that are arranged in time and space. The equation for the pooled data set can be written as follows;

$$
Y_{i t}=\alpha+X_{i t}^{\prime} \beta_{i t}+\delta_{i}+\gamma_{t}+u_{i t}
$$

$\mathrm{Y}_{\mathrm{ti}}$ represents the dependent variable, $\mathbf{X}_{\mathbf{i t}}$ is the vector independent variable $\mathrm{k}$, and the $\mathbf{u}_{\mathrm{it}}$ is the error term. As for the equation $\mathrm{I}=1.2 \ldots . \mathrm{M}$, It refers to the number of horizontal sections in each period defined as $\mathrm{t}=1.2 \ldots . \mathrm{T}$. $\alpha$ represents the general constant in the model, and $\delta \mathrm{i}$ and YT refer to the horizontal section or periodic subjective specific effects (random and fixed effects). $\beta$ coefficient must be limited in case of determination. It occurs in the form of horizontal or periodic subjective parameters.

Our equation $\mathrm{M}$ horizontal cross-section equation and $\mathrm{T}$ observation is as the following;

$$
Y_{i t}=\alpha l_{T}+X_{i}^{\prime} \beta_{i t}+\delta_{i} l_{T}+I_{T} \gamma+u_{i}
$$

Here $\mathrm{i}=1,2 \ldots \mathrm{m}, \mathrm{TT}$ is the unit vector with $\mathrm{T}$ element, and IT is the unit matrix with $\mathrm{T}$ element $\mathrm{t}$, and $\gamma$ is a vector containing periodic effects; $\left(\gamma^{\prime}=\left(\gamma_{1}, \gamma_{2}, \ldots \ldots . \quad \gamma_{\mathrm{T}}\right)\right.$

In the estimated models, horizontal cross-section and periodic effects can be treated as fixed and random effects. The dimensions of the effects can be provided with certain limitations on the model.

For example, seeing fixed effects in the horizontal section, random effects in the periodic data, or vice versa. Only for two-way data for random effects, data must be balanced, and each horizontal section must bear the same observation value.

Fixed Effects: The properties of constant effects are discussed in orthogonal projections. This model is used to estimate the omnidirectional element of error in very unbalanced data.

Random Effects: The random errors acknowledge that the specification is not in the (unusual) correlation with the effects idiosyncratic residues.

In Fixed Effects or random effects model, $e_{i}$ is not directly observable. As a natural result of the last equation, $\mathrm{E}\left(\mathrm{v}_{\mathrm{i}}\right)=0$ and $\mathrm{var}=\sigma_{e}{ }^{2}+\sigma_{u}^{2}$.If $\sigma_{e}{ }^{2}=0$ in the Estimation made, There is no difference between the Fixed effects model Estimation and that of pooled regression model.

\section{Empirical Results}

The trade volume between Turkey and the five BRICS countries in the period between 1992-2016 is estimated by the gravity model analysis. The data used in the study was obtained from the World Bank (https://data.worldbank.org/) site. The following figure 1 includes graphs of this data. 

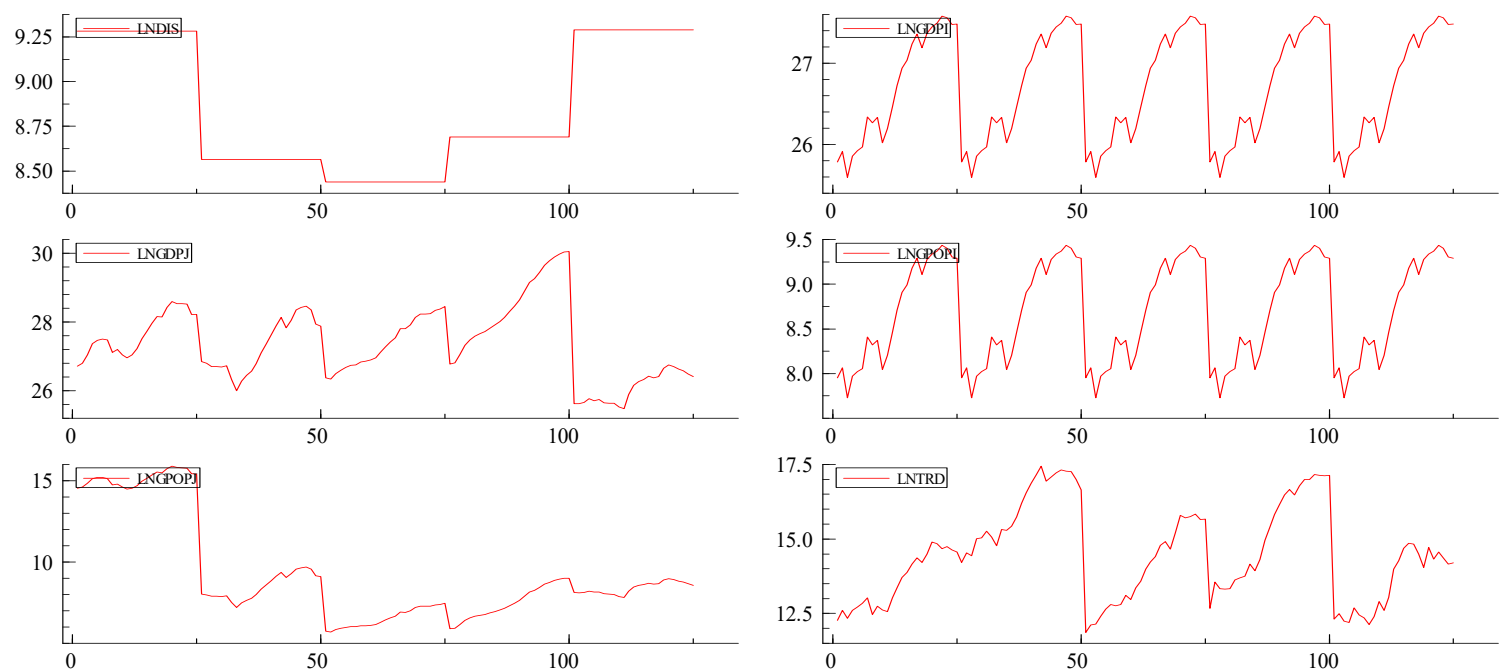

Figure 1. Data

Here, two different panel Estimations have been done. The first is a model in which not the population but only the countries ' GDP and the distances are involved, and the model is the one in which population is also involved. In the model where the population is included, the GDP is divided into the population. In other words, per capita income is calculated.

\subsection{The Estimation Involving GDPs}

We can express the gravity equation to be used in the following panel estimation as follows:

$$
\ln E_{i j}=\alpha+\beta_{1} \ln G D P_{i}+\beta_{2} \ln G D P_{j}+\beta_{3} \ln D_{i j}
$$

We can express the gravity equation which will be used in the panel Estimation below that we will use in our study in the following format.

The logarithms of all the variables we will use in this study are taken. LNTRD shows Turkey's trade volume with the BRICS countries (imports + exports); LNGDPI shows the logarithm of GDP of the trading country; LNGDPJ shows the logarithm of the traded countries; InPOPI and $\operatorname{lnPOPj}$ show in the same way the population of $i$ and $j$ countries. As for LNDIS, it refers to the distance between countries. The following table shows the estimated gravity model of trade between the five countries and Turkey are scheduled BIRCS.

As shown in the table, random effects are the result of Estimation (egls two-way random effects). The random effects model is understood to be the most appropriate estimation method, as can be understood from the test results given below. Y It is seen that the R2 value of the estimate is $90 \%$, the value of the F statistic is very high and the model of P (Prob (F-statistic)) is significant at 1\% significance level. Based on the estimated coefficients, both the positive coefficient of the GDP of both countries makes sense at a $1 \%$ significance level of the coefficient. Parameter coefficients are consistent with the assumption of the theory. The sign of LNDIS coefficient seems to be consistent with the theory, but not statistically significant. That is, the distance between countries does not confirm the thesis that there is an inverse proportion or reduction effect on the amount of trade between countries. However, the negative of the parameter is compatible with the theory, but, the value of this coefficient is not significant. 
Table 1. Turkey's Foreign Trade Estimation for BRICS Countries

Dependent Variable: LNTRD

Method: Panel EGLS (Two-way random effects)

Sample: 19922016

\begin{tabular}{lllll}
\hline \hline Variable & Coefficient & Std. Error & t-Statistic & Prob. \\
\hline \hline LNGDP $_{\mathrm{I}}$ & 0.930124 & 0.097355 & 9.553956 & 0.0000 \\
LNGDP & 0.770821 & 0.082803 & 9.309038 & 0.0000 \\
LNDIS & -1.131204 & 1.456452 & -0.776684 & 0.4389 \\
C & -21.47350 & 12.98356 & -1.653898 & 0.1007 \\
\hline \hline
\end{tabular}

Effects Specification

S.D. Rho

\begin{tabular}{|c|c|c|c|}
\hline $\begin{array}{l}\text { Cross-section random } \\
\text { Period random } \\
\text { Idiosyncratic random }\end{array}$ & & $\begin{array}{l}1.181435 \\
0.124713 \\
0.275646\end{array}$ & $\begin{array}{l}0.9385 \\
0.0105 \\
0.0511\end{array}$ \\
\hline & \multicolumn{3}{|c|}{ Weighted Statistics } \\
\hline $\begin{array}{l}\text { R-squared } \\
\text { Adjusted R-squared } \\
\text { S.E. of regression } \\
\text { F-statistic } \\
\text { Prob(F-statistic) }\end{array}$ & $\begin{array}{l}0.905032 \\
0.902678 \\
0.274166 \\
384.3722 \\
0.000000\end{array}$ & $\begin{array}{l}\text { Mean dependent var } \\
\text { S.D. dependent var } \\
\text { Sum squared resid } \\
\text { Durbin-Watson stat }\end{array}$ & $\begin{array}{l}0.672987 \\
0.878834 \\
9.095183 \\
0.574466\end{array}$ \\
\hline Prob(F-statistic) & \multicolumn{3}{|c|}{ Unweighted Statistics } \\
\hline $\begin{array}{l}\text { R-squared } \\
\text { Sum squared resid }\end{array}$ & $\begin{array}{l}0.686795 \\
96.67895\end{array}$ & $\begin{array}{l}\text { Mean dependent var } \\
\text { Durbin-Watson stat }\end{array}$ & $\begin{array}{l}14.45404 \\
0.066625\end{array}$ \\
\hline
\end{tabular}

Above mentioned panel estimation was used in random effects model. The effect of the random effects model is determined by the following Hausman test. It is understood from the given Hausman test that this model is the most suitable model. When the test result is examined, it is possible to see the chi-square statistics (Chi-Sq. Statistic (x2)). In the first part of the table, P probability values are quite high, zero hypothesis is accepted. In the second part of the table, constant effects and random effects are estimated and the difference between coefficients is the same.

Table 2. Hausman Test Results

Correlated Random Effects - Hausman Test

Equation: Untitled

Test cross-section and period random effects

\begin{tabular}{llll}
\hline \hline Test Summary & Chi-Sq. Statistic & Chi-Sq. d.f. & Prob. \\
\hline \hline Cross-section random & 0.247612 & 2 & 0.8836 \\
Period random & 0.195158 & 2 & 0.9070 \\
Cross-section and period random & 0.386529 & 1 & 0.5341 \\
\hline \hline
\end{tabular}

Table 3.Cross-section random effects test comparisons

\begin{tabular}{lllll} 
Variable & Fixed & Random & Var(Diff.) & Prob. \\
\hline \hline LNGDPI & 0.923899 & 0.930124 & 0.000186 & 0.6479 \\
LNGDPJ & 0.777083 & 0.770821 & 0.000158 & 0.6188 \\
\hline \hline
\end{tabular}




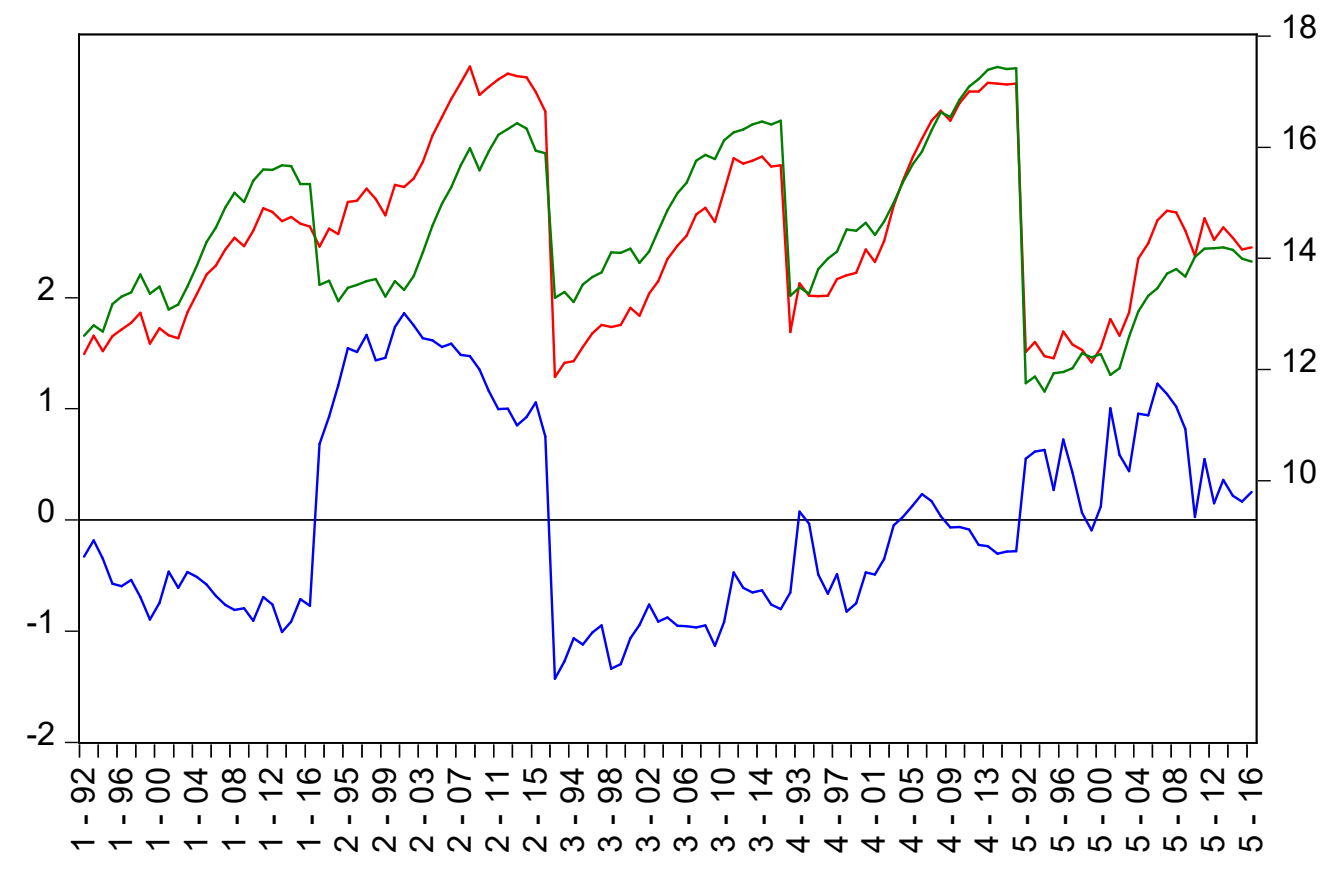

\section{Residual _ Actual _ Fitted}

Figure. 2 Turkey-BRICS Countries Forecast

4.2. The Estimation Involving GDP and Population

The Estimation equation of the gravitational model in which the population is included is designed as; $\ln E_{i j}=\alpha+\beta_{1} \ln \left(G D P_{i} / P O P_{i}\right)+\beta_{2} \ln \left(G D P_{j} / P O P_{j}\right)+\beta_{3} \ln D_{i j}$.

GDPs are divided by the population and income per capita is obtained. This equation is expected to give more meaningful results than the previous equation. below.

The random effects model is the most appropriate estimation method as can be seen from the test results given

It is seen that the R2 value of the estimation is $88 \%$, the value of $\mathrm{F}$ statistic is very high (313.4) and the whole of the model is significant at $1 \%$ significance level when P (iProb(F-statistic) is considered. When the estimated coefficients are taken into consideration, it is seen that the GDP / POP values of the country are significant for both parameter coefficients with positive coefficients of $1 \%$ significance level. Parameter coefficients are consistent with the assumption of the theory. The index coefficient seems to be consistent with the Sign theory, and it is understood that $\mathrm{X} 2$ values are high and P probability values are very low. It clearly attracts the attention that the distance between countries is inversely proportional to the amount of trade between countries or has a mitigating effect. Considering the above two models, the Estimation involving the population has a higher level of significance. So, it is understood that the Estimation involving the population the most appropriate model to describe the trade between BRICS countries and Turkey. 
Table 4. Turkey's foreign trade forecast, including the population related to the countries of the BRICS

Dependent Variable: LNTRD

Method: Panel EGLS (Two-way random effects)

Sample: 19922016

Total panel (balanced) observations: 125

Swamy and Arora estimator of component variances

\begin{tabular}{lllll}
\hline \hline Variable & Coefficient & Std. Error & t-Statistic & Prob. \\
\hline \hline LNGPOPI & 1.320841 & 0.101611 & 12.99906 & 0.0000 \\
LNGPOPJ & 0.653373 & 0.075044 & 8.706505 & 0.0000 \\
LNDIS & -5.611733 & 1.582256 & -3.546666 & 0.0006 \\
C & 46.63677 & 14.02283 & 3.325774 & 0.0012 \\
\hline \hline
\end{tabular}

Effects Specification

\begin{tabular}{llc} 
& S.D. & Rho \\
\hline \hline Cross-section random & 1.204795 & 0.9373 \\
Period random & 0.143167 & 0.0132 \\
Idiosyncratic random & 0.276856 & 0.0495 \\
\hline \hline
\end{tabular}

\begin{tabular}{|c|c|c|c|}
\hline \multicolumn{4}{|c|}{ Weighted Statistics } \\
\hline R-squared & 0.885995 & Mean dependent var & 0.662661 \\
\hline Adjusted R-squared & 0.883168 & S.D. dependent var & 0.826421 \\
\hline S.E. of regression & 0.282476 & Sum squared resid & 9.654938 \\
\hline F-statistic & 313.4514 & Durbin-Watson stat & 0.572803 \\
\hline \multirow[t]{2}{*}{ Prob(F-statistic) } & 0.000000 & & \\
\hline & \multicolumn{3}{|c|}{ Unweighted Statistics } \\
\hline R-squared & -0.013227 & Mean dependent var & 14.45404 \\
\hline Sum squared resid & 312.7586 & Durbin-Watson stat & 0.024624 \\
\hline
\end{tabular}

As in the previous estimate, the random effects model was used in the panel estimation of the population. The effect of the random effects model is determined by the following Hausman test. When the test result is examined, it is possible to see the chi-square statistics (Chi-Sq. Statistic (x2)). In the first part of the table, the probability values of $\mathrm{P}$ are quite high, and the null hypothesis is definitely accepted. In the second part of the table, constant effects and random effects are estimated and it is understood from the $p$ values that the difference between coefficients is the same. When we look at these results, it turns out that the estimation of random effects is the most appropriate estimation method in both estimation equations.

It is understood from the Hausman test that the random effects model is best suited to the Estimation. Looking at the test result, the null hypothesis is clearly accepted.

Table 5. Hausman Test

Correlated Random Effects - Hausman Test

Equation: Untitled

Test cross-section and period random effects

\begin{tabular}{llll}
\hline \hline Test Summary & Chi-Sq. Statistic & Chi-Sq. d.f. & Prob. \\
\hline \hline Cross-section random & 0.000000 & 2 & 1.0000 \\
Period random & 0.000000 & 2 & 1.0000 \\
Cross-section and period random & 2.644410 & 1 & 0.1039 \\
\hline \hline
\end{tabular}

* Cross-section test variance is invalid. Hausman statistic set to zero.

* Period test variance is invalid. Hausman statistic set to zero. 
Tablo 6.Cross-section random effects test comparisons

\begin{tabular}{lllll} 
Variable & Fixed & Random & Var(Diff.) & Prob. \\
\hline \hline LNGPOPI & 1.258708 & 1.320841 & 0.000151 & 0.0000 \\
LNGPOPJ & 0.714747 & 0.653373 & 0.000322 & 0.0006 \\
\hline \hline
\end{tabular}

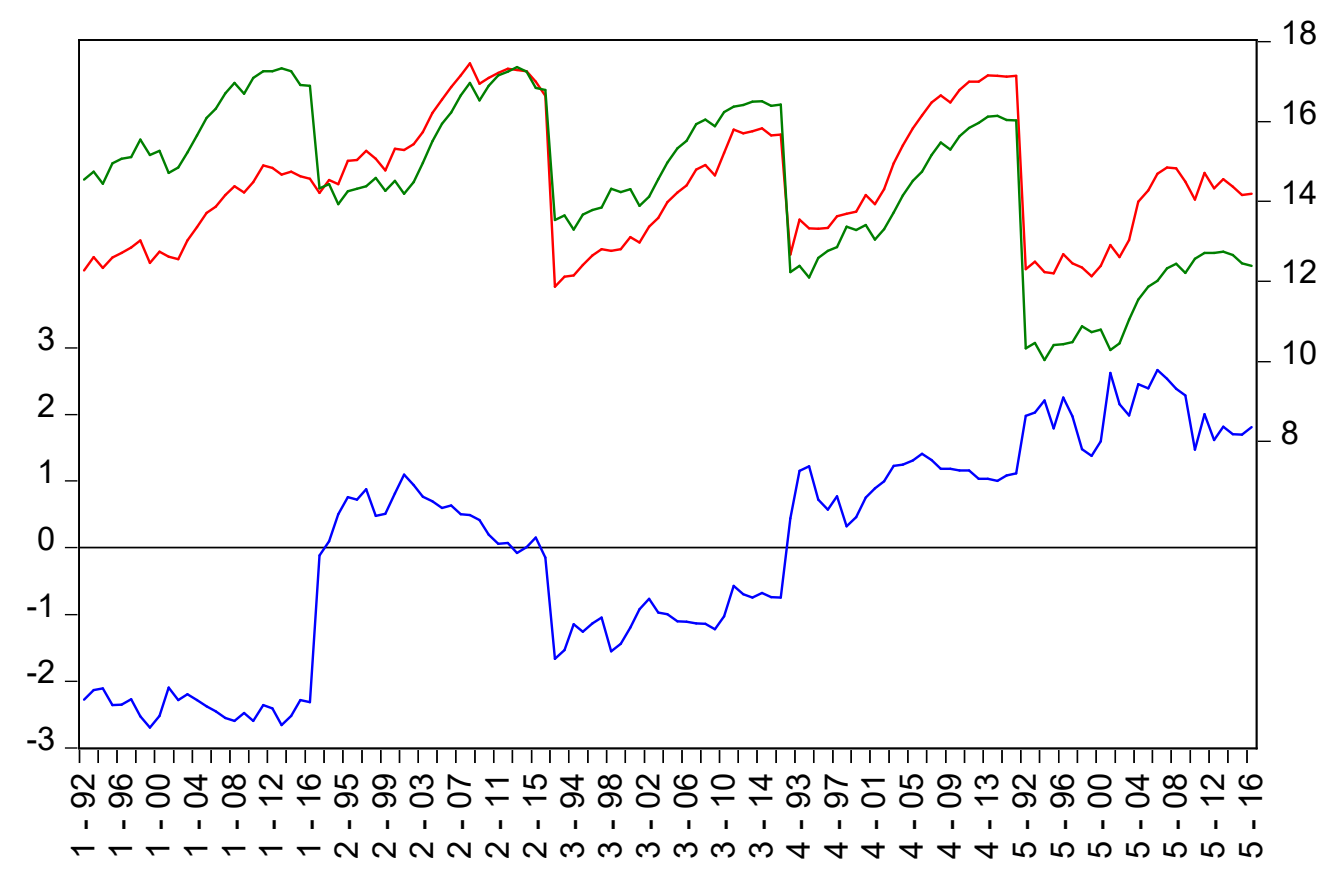

\section{- Residual _ Actual _ Fitted}

Figure- 3 Estimation Results Actual and Residual Values
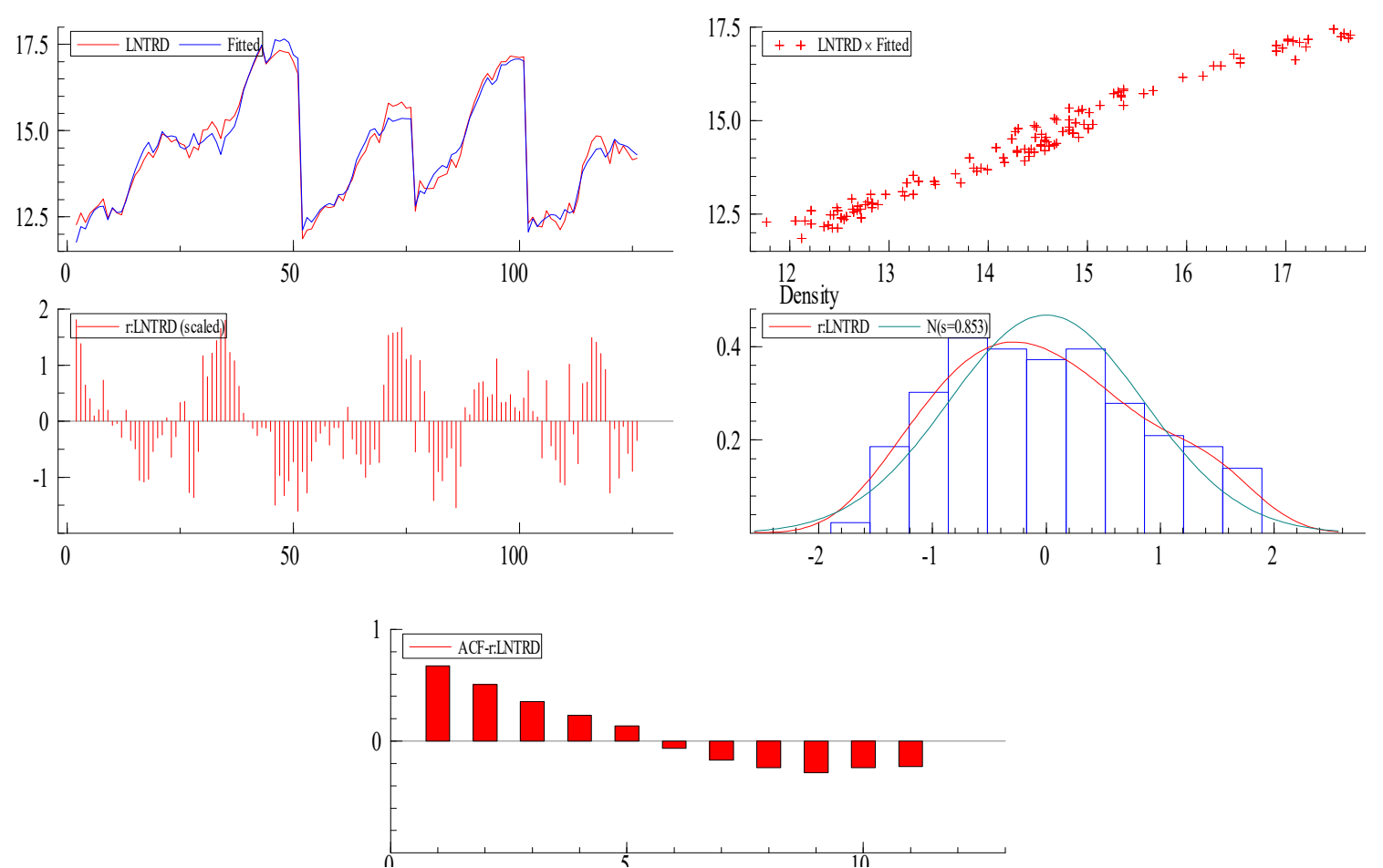

Figure 4. Estimations of The Most Appropriate Model 


\section{Conclusion}

In this study, the estimate of Turkey's trade volume with five BRICS countries was taken into consideration with the gravity model. 25-year data sets of the tears between 1992-2016 were used and trade volume in this data sets was considered as dependent variables. While the study uses two models, in one model, the countries' GDP and the distances are used as independent variables, while in the second model, the population of the countries are included in these variables.

As a result of the panel analysis, while the GDPs of the Turkey and BRICS countries confirmed the positive relationship, the coefficient value for the distance was not statistically significant. In the second model, when the population was included, it was determined that all variables had significant and theoretical signs. Thus, 25 years of development in foreign trade volume between Turkey and the BRICS countries coincides with the Estimations of the theory of gravity models. When the population is included, it can be said that the calculations made in the form of GDP per capita yielded more accurate results.

\section{References}

Anderson, J. E. (1979). A Theoretical Foundation for the Gravity Equation. American Economic Review,69 (1): 106-116. A First Attempt to Provide Theoretical Foundations to the Gravity Model.

Armington, P. (1969). A Theory of Demand for Products Distinguished by Place of Production. IMF Staff Papers, 16 (3): 159-176. The Key Contribution on Product Differentiation by Country of Origin.

Baltagi, B. H. and Young-Jae Chang (1994). "Incomplete Panels: A Comparative Study of Alternative Estimators for the Unbalanced One-way Error Component Regression Model," Journal of Econometrics, 62: 67-89.

Baltagi, B. H. (2008). Econometric Analysis of Panel Data, 4th ed. New York: John Wiley \& Sons.

Cheng Hsiao (2003). Analysis of Panel Data, Cambridge University Press,2nd edition

Tinbergen, J. (1962). "Shaping the world economy. Suggestions for an international economic policy", The Twentieth Century Fund, New York

Damodar N. Gujarati, and Dawn C. Porter (2009). Basic Econometrics 5th Edition (by) McGraw-Hill Series

Ekanayake E. M. (2010). Trade Blocks and the Gravity Model: A Study of Economic Integration among Asian Developing Countries, Journal of Economic Integration, 25 (4)

Erdem E, Nazlioglu S. (2008). Gravity Model of Turkish Agricultural Exports to the European Union, International Trade and Finance Association Working.

Evenett, S. J., Keller, W. (1998), On the Theories Explaining the Success of the Gravity Equation, NBER Working Paper No. 6529, Cambridge, MA: National Bureau of Economic Research

Frankel, J., Romer, D. (1999), Does Trade Cause Growth?, American Economic Review, 89(3): 379-399.

Frankel, J., Stein, E., Wei, S. (1995), Trading Blocs and the Americas, Journal of Development Economics, 47(1): 61-95.

Frede ,J. and Yetkiner, H. (2017) The Regional Trade Dynamics of Turkey: A Panel Data Gravity Model The Journal of International Trade \& Economic Development An International and Comparative Review ISSN: 0963-8199 (Print) 1469-9559 (Online) Journal Homepage: http://www.tandfonline.com/loi/rjte20

Helpman, E. and Krugman, P. (1985). Market Structure and Foreign Trade. Cambridge, MA: MIT Press.

Hsiao, C., Pesaran M. H., and Andreas Pick (2012). "Diagnostic Tests of Cross Section Independence in Limited Dependent Variable Panel Data Models," Oxford Bulletin of Economics \& Statistics, 74: 253-277.

Pöyhönen, P. (1963), “A Tentative Model for the Volume of Trade Between Countries", Weltwirtschaftliches Archiv 90: 93-99.

Sezai Ata (2013). International Conference On Eurasian Economies Türkiye ile Komşuları Arasındaki Ticaret Potansiyeli: Çekim Modeli Çerçevesinde Bir İnceleme Turkey's Trade with Neighbour Countries:A Gravity Model Analysis

William H. G. (2003). Econometric Analysis Q Pearson Education, Fifth Edition, LTD New York University 